\section{Eke CB \\ Onyire NB Amadi OF}

DOI:http://dx.doi.org/10.4314/njp.v43i3.9

Accepted: 2nd June 2016

Eke CB ( $\quad$ )

Department of Paediatrics,

College of Medicine, University of

Nigeria, Enugu Campus, Nigeria.

Email: christopher.eke@unn.edu.ng

Onyire NB

Department of Paediatrics, College of Medicine, Ebonyi State University, Abakaliki/Federal Teaching Hospital Abakaliki, Nigeria.

Amadi OF

Department of Paediatrics,

College of Medicine, Enugu State University of Science and Technology (ESUT)/ESUT Teaching Hospital Park Lane Enugu, Nigeria.

\title{
Prevention of mother to child transmission of hepatitis $B$ virus infection in Nigeria: A call to action
}

\begin{abstract}
Background: Sub- Sahara Africa including Nigeria has the second largest global burden of chronic carriers of hepatitis $\mathrm{B}$ virus (HBV) infection after Asia. Mother-to-child transmission (MTCT) of HBV is the most commonroute of transmission in high endemic areas .MTCT of hepatitis $B$ virus infection continues to occur despite the interventions of hepatitis B vaccinations and immunoglobulins in settings where it is practiced. Infants most at risk are those whose mothers have high HBV DNA viral loads and produce the protein $\mathrm{HBeAg}$. Various Nigerian studies have reported high $\mathrm{HBV}$ infection rates as well as $\mathrm{HBeAg}$ positivity among pregnant women.
\end{abstract}

These HBV infections usually occur intrapartum and rarely inutero. Mothers with $\mathrm{HBeAg}$ positivity known to be associated with higher HBV DNA viral loads have been linked with higher chances of MTCT as HBeAg is the only structural $\mathrm{HBV}$ protein that can cross into the placental circulation.

In the absence of post exposure prophylaxis about 40 percent of infants delivered by HBV infected mothers could develop HBV infections, and about $25 \%$ of them may come down with chronic hepatitis and resulting possible complications including liver cirrhosis and hepatocellular cancer later in life.

The prevention of transmission of retroviral infection from motherto-child has been a success story of the $21^{\text {st }}$ century and such feat could be replicated for $\mathrm{HBV}$ infection. The standard PMTCT of HBV currently will comprise: timely prenatal screening, starting anti-viral therapy for pregnant women with $\mathrm{HBeAg}$ positivity and high viral load, infant postexposure prophylaxis and followup of infants of HBsAg positive mothers.

There is no co-ordinated PMTCT of $\mathrm{HBV}$ programme in place in our setting despite the huge burden of the disease in Nigeria. Hence the need therefore to develop a home grown PMTCT programme of HBV to help tackle the burden of the disease in our country. An evidence based review of current best practice guidelines for the prevention of mother-to-child transmission of HBV for use in low and medium resource income settings with hepatitis B hyperendemicity will be quiet apt in this circumstance.

This document therefore will be useful as a quick guide to Paediatricians, Obstetricians, Family Physicians, General Practice Doctors and other allied health workers charged with the care of pregnant mothers and their young children.

Methods: Relevant literatures published in English language or translated into English were searched manually and electronically in PUBMED and SCOPUS for the period between 1990 and 2016 on the subject. Keywords searched included: epidemiology of HBV infection, MTCT of HBV, and its preventive strategies including prenatal screening, antiviral agents in pregnancy, infant post exposure prophylaxis and follow-up of infected children.

Results: Over 35 scholarly articles on HBV epidemiology, MTCT, and preventive measures as well as follow -up models were retrieved and analyzed.

Conclusion: Universal screening of all pregnant women for HBV infection is the most effective 
strategy for the prevention of MTCT of HBV, as effective preventive measures could be applied starting from pregnancy to delivery while infants of HBsAg posi- tive mothers should receive timely post exposure prophylaxis and followed up for possible development of chronic hepatitis B infection.

\section{Introduction}

Hepatitis B virus (HBV) infection is a potentially life threatening liver infection. It is a major global public health problem and known to cause chronic hepatitis with high risk of mortality resulting from hepatic cirrhosis and cancer. ${ }^{1}$ Sub-Sahara Africa has the second largest global burden of chromic carriers of HBV infection after Asian continent. ${ }^{2}$ Estimates of hepatitis B antiginaemia seroprevalence of $6-20 \%$ have been reported, making Sub-Sahara Africa a hyper-endemic region. ${ }^{3,4}$ Nigeria also is a hyper-endemic country for HBV infection, with varying reported rates ranging from 0.5 to 44.7 percent in children. ${ }^{5-9}$

In highly endemic regions HBV infection is commonly spread from mother to child prenatally, during the period of delivery (perinatal transmission), or through horizontal transmission (exposure to infected blood/ body or other fluids) particularly from an infected child to an uninfected child during the first five years of life ${ }^{1,10}$ In Nigeria varying reports of horizontal as well as vertical transmission as the most common route of HBV transmission in children exist. ${ }^{11,12}$

MTCT has also been shown to occur during pregnancy and/or delivery. ${ }^{13}$ Mother-to-child transmission (MTCT) of $\mathrm{HBV}$ infection has been reported to be responsible for over a third of cases of chronic HBV infections worldwide. ${ }^{14}$ Hepatitis $\mathrm{B}$ infection in pregnancy poses a serious threat to the infant at birth.

In the absence of post exposure prophylaxis, about 40 percent of infants delivered by HBV infected mothers could develop HBV infections, and about $25 \%$ of whom will die resulting from complications of chronic liver disease. ${ }^{14}$ Several Nigerian studies in pregnant women have reported HBV rates between 8.3 to 12.8 percent. $^{11,15,16,17}$

MTCT of hepatitis B virus infection continues to occur despite the interventions of hepatitis $B$ vaccinations and immunoglobulins in settings where it is practiced. ${ }^{14}$ It is pertinent to understand that the most significant risk factor in transmission of $\mathrm{HBV}$ is high maternal viral load. ${ }^{18}$

Nigerian studies have shown high levels of HBeAg positivity in pregnant women. ${ }^{19,20}$

Despite presence of hepatitis B surface antigen positivity, presence of $\mathrm{HBeAg}$ mothers with HBV DNA levels greater than or equal to $10^{6}$ copies per mililitre (greater than $200,000 \mathrm{in} / \mathrm{ml}$ ) are at greatest risk of transmitting HBV to their infants. ${ }^{21}$

Screening pregnant women for HBsAg (HBV infection), starting anti-viral therapy for those with $\mathrm{HBeAg}$ positivity and high viral load, providing infant post-exposure prophylaxis (PEP) using the administration of hepatitis $B$ vaccine within 24 hours of birth followed by completion of the HBV vaccine series; are recognized strategies for reducing MTCT transmission rates and the global burden of a new chronic HBV infection. ${ }^{10,22}$

The World Health Organization has actively initiated responses to the control of HBV pandemic through promoting the prevention of its transmission. ${ }^{13}$

Of note also is that even where women have access to birth dose vaccine of $\mathrm{HBV}$ and hepatitis B immunoglobulin there remains a 5-10 percent failure rate. This occurs in women with high HBV viral loads.In this group of mothers, antiviral therapy during pregnancy has been shown to significantly reduce the risk of MTCT. ${ }^{23}$ In circumstances where mothers do not need the anti-viral therapy for their own (HBV infection) health; the antiviral therapy could be used during pregnancy with the aim of reducing the risk of MTCT of HBV.

Considering that the prevention of transmission of retroviral infection from mother-to-child has been a success story in this $21^{\text {st }}$ Century. ${ }^{22}$ Such fit could be replicated for HBV infection particularly in hyperendemic settings like ours.

However gaps still exist on the current recommendations for managing $\mathrm{HBV}$ infected mothers as well as their exposed infants particularly in our setting. Also failure in follow-up of $\mathrm{HBV}$ exposed infants abound despite the potential complications associated with chronic HBV infections particularly liver cirrhosis and hepatoma.

It therefore becomes pertinent to review the literature on the current best practice guidelines on prevention of mother-to-child transmission (PMTCT) of HBV infection in other to further empower our clinicians particularly Obstetricians and Paediatricians alike as well as other allied health professionals in addressing this problem adequately in other to reduce the burden of HBV through vertical transmissions in high endemic settings like ours.

Nigeria has introduced the birth dose of hepatitis B vaccine as well other primary series hepatitis B vaccination since 2004. ${ }^{9}$ The birth dose of HBV vaccine has been shown to be strategic towards PMTCT of HBV, however ensuring universal HBsAg screening in pregnancy, starting anti-viral therapy for pregnant women with $\mathrm{HBeAg}$ positivity and high viral load, timely administration of the birth dose of HBV vaccination and follow-up of exposed infants will remarkably help to realize this objective of PMTCT of HBV. Also efforts should be made to educate carrier mothers (after testing) and their families on the prevalent risk factors and essence of pre- 
ventive measures.

Current implications are that there is urgent need for Nigeria and other countries in the Sub- Sahara Africa as well as Asia where hyper-endemicity of HBV exist to articulate evidence - based, home adaptable and sustainable programmes on prevention of mother-to-childtransmission of HBV geared towards the eradication of the HBV infection.

In Nigeria the current national programme on the PMTCT of human immune deficiency virus (HIV) infection could be leveraged upon in the realization of HBV prevention. All that is needed is the political will, which basically implies political strategic financial investment in the programmes to make the PMTCT of HBV in Nigeria - a dream come true.

\section{Hepatitis B Virus Pathology}

The HBV is a member of the hepadnaviridae family (a hepatotropic group of DNA viruses). ${ }^{9,24}$

The mature HBV virion is a spherical double layered "Dane particle" that has 4 different genes including the outer surface envelop of glycoprotein (hepatitis B surface antigen; $\mathrm{HBsAg}$ ); an inner portion of the virion designated as hepatitis $\mathrm{B}$ core antigen ( $\mathrm{HBcAg}$ ), the nucleocapsid which encodes the viral DNA and a nonstructural antigen known as hepatitis B epsilon (e) antigen $(\mathrm{HBeAg})$. The HBeAg is a non-particulate soluble antigen from $\mathrm{HBeAg}$ by proteolytic self clearage.

The $\mathrm{HBeAg}$ is a marker of active viral replication and correlates favourably with HBV DNA levels. The HBV virion also contains a DNA polymerase which exhibits reverse transcriptase activity and genomic replication occurs through an intermediate RNA template as well as protein from the $\mathrm{x}$-region ( $\mathrm{HBX}$ ) which is needed for the viral replication and acts as a transcriptional transactivator of the viral genes and a wide range of host gene parameters. ${ }^{24,25}$

The replication of HBV occurs usually in the liver; however it could occur in the lymphocytes, spleen, kidneys, and pancreas. ${ }^{24,25}$

\section{Mother-to-child transmission of hepatitis B virus infec- tion}

Prior to the era of the introduction of universal hepatitis $B$ vaccinations the possible risk of a child becoming a chronic carrier of hepatitis B virus infection was about10 - 30percent if born to mother who is HBsAg positive but $\mathrm{HBeAg}$ negative; and up to $90 \%$ if mother is also $\mathrm{HBeAg}$ positive. ${ }^{6,22,26}$

The most important risk factor for the transmission of hepatitis B in pregnancy is the maternal HBV DNA levels. It has also been proven that failures in MTCT infant post exposure prophylaxis (PEP) usually occur in mothers with HBV DNA viral threshold of $\geq 10^{6}$ to $\geq 10^{8}$ copies per mililitre. ${ }^{21}$ Maternal acquisition of HBV infection particularly in third trimester of pregnancy or intrapartum carries the highest risk of transmission of HBV infection. $^{21}$

The risk of maternal transmission of HBV infection in pregnancy and peri-natal period is dependent on maternal $\mathrm{HBeAg}$ positively. Mothers with positive $\mathrm{HBeAg}$ have a transmission rate of 70-90 percent whereas those with a negative $\mathrm{HBeAg}$ have a rate probably less than $10 \% .^{26,27}$

However the precise mechanism of HBV transmission remains largely uncertain but it appears that infection may occur intrapartum, or rarely, in-utero.

Hepatitis B viral DNA and HBsAg have been detected in amniotic fluid, placental cells and virginal secretions of $\mathrm{HBsAg}$ positive women during pregnancy and in cord blood of their neonates. $^{28}$

\section{Prenatal transmission}

The possibility of prenatal transmission of $\mathrm{HBV}$ has been speculated to be low.However, mothers with $\mathrm{HBeAg}$ positivity known to be associated with higher HBV DNA viral loads have been linked with higher chances of MTCT as HBeAg is the only structural HBV protein that can cross into the placental circulation. ${ }^{22,29}$

\section{Intra-partum transmission}

The intra-partum period has been shown to be associated with higher chances of MTCT of HBV.

This exposure occurs via micro-transfusion or haematologic leaks of maternal blood to the fetus during contractions or through inoculations of mucosal membranes or breaks in the skin (e.g. during some obstetric procedures including insertion of fetal scalp electrodes in settings where it is practised. ${ }^{30}$

The mode of delivery (vaginal or caesarean section) does not seem to increase or decrease the risk of perinatal HBV infection. ${ }^{28}$ Most studies found no difference in MTCT among babies delivered by caesarean or spontaneous versus operative vaginal deliveries among infants who received post exposure prophylaxis (PEP).

However there is no consensus recommendation as per the preferred mode of delivery in high risk mothers.

\section{Breastfeeding}

Though possible markers of HBV have been demonstrated in breast milk and colostrum from $\mathrm{HBsAg}-$ positive women; ${ }^{26}$ transmission of $\mathrm{HBV}$ through breast milk is not a significant source of infection, as reported in some pre- HBV routine neonatal prophylaxis studies. ${ }^{31,32}$

Reported prevalence of HBV infection in breastfed and non-breastfed infants appear same, however, some of the studies did not take maternal HBV DNA viral load into cognizance. Also, mothers with cracked or bleeding nipples may momentarily stop breastfeeding as meta- 
analysis of studies among mothers with absence of such symptoms did not identify an increase in MTCT rates of HBV when breastfed babies received post exposure prophylaxis (PEP). ${ }^{22}$

It is recommended that HBV positive mothers should breastfeed their infants provided that the infants receive timely and adequate PEP at birth.

\section{Clinical features}

Most cases of acute HBV infection usually manifest with non-specific presentations including nausea, vomiting, loss or poor appetite, fever, myalgia and weakness. $^{22}$

One percent of cases of acute hepatitis including those occurring in neonatal period may develop fulminant hepatitis. Course of cases of acute, fulminant hepatitis B virus infection could be irreversible and result in liver failure with possible mortality. ${ }^{33}$

Majority of cases of HBV infections including acute and chronic hepatitis are asymptomatic. Chronic HBV infection however has three immunologic phases: immune tolerant (absent or minimal liver inflammation, high viraemia); immune active (alanine amino-transferase rises, high viraemia, liver inflammation rises; high viraemia, liver inflammation, and fibrosis improve, anti$\mathrm{HBe}$ is present); and the inactive chronic hepatitis (the non-replicative or inactive immune-control phase) which follows successful sero-conversion from an $\mathrm{HBeAg}-$ positive to anti-HBe state. ${ }^{34}$

The immune tolerant phase usually appears in individuals who had perinatal infection from $\mathrm{HBeAg}$ positive mothers.

\section{Preventive measures \\ Prenatal hepatitis $b$ virus infection screening}

Chronic HBV infection is characterized by the presence of HBsAg for at least 6 months (with or without concurrent $\mathrm{HBeAg}$ positivity). The persistence of $\mathrm{HBsAg}$ is the principal marker of risk of developing chronic liver disease and hepatocellular carcinoma later in life. ${ }^{9}$

It is recommended that all pregnant women should be tested routinely for $\mathrm{HBsAg}$ during an early prenatal visit (preferably in the first trimester) in every pregnancy irrespective of if they had been previously vaccinated for HBV or tested. ${ }^{1}$

Un-booked pregnant mothers or women who were not screened prenatally particularly those who engage in behaviours that put them at high risk for infection especially intravenous drug users, those with more than one sexual partners in the previous six months or an $\mathrm{HBsAg-}$ positive sex partner, evaluation or treatment for a sexually transmitted disease and those with clinical hepatitis should be tested at the time of admission to the hospital for delivery. ${ }^{35}$

The prenatal HBsAg screening is key to successful HBV
PMTCT programme as the maternal status is obtained early enough and appropriate measures applied. ${ }^{36}$

Rapid immunochromatographic hepatitis B surface antigen tests with acceptable performance are available to identify HBV infected pregnant women. ${ }^{21}$

Cost-effective point-of-care tests for combined $\mathrm{HBsAg}$ and $\mathrm{HBeAg}$ detection and determination of $\mathrm{HBV}$ viral load are currently being developed ${ }^{37}$ and further resources should be channeled towards making it a success story.

\section{Prenatal prevention for mothers}

The maternal $\mathrm{HBeAg}$ positivity as well as elevated HBV DNA viral load are directly related to rate of intrauterine transmission. ${ }^{38}$ Therefore reduction of maternal DNA viral load of $\mathrm{HBV}$ is an effective method of decreasing the rate of $\mathrm{HBV}$ infection in infants particularly in endemic areas. ${ }^{39,40}$

\section{Use of anti-viral agents in pregnancy}

The probable reasons for use of anti- viral (antiretroviral) therapy in chronic hepatitis B in pregnancy are based on maternal viral load, liver enzyme levels (liver function test), $\mathrm{HBeAg}$ status, liver histology, and HIV co-infection status. ${ }^{41}$

The benefits of anti- retroviral (ARV) prophylaxis during pregnancy is to decrease viraemia so as to limit breakthrough HBV infection. ${ }^{41}$ The administration of anti- retroviral therapy (ART) starting from late pregnancy will reduce maternal HBV viral load and potentially reduce the possible risk of MTCT. ${ }^{42}$

The use of antiviral agents during pregnancy mainly for prophylaxis of perinatal HBV transmission would entail diligent evaluation of potential risks and benefits among infants and their pregnant mothers alike. ${ }^{43}$ Some studies in animal specimens have shown severe growth restriction and reduced bone mineral density in exposed fetuses to ART.

However, recent efficacy data on prophylaxis of PMTCT of HBV have shown acceptable safety profile in pregnant women. Equally commencement of the ART in the third trimester of pregnancy among mothers with high viral load (e.g. $\geq 10 \mathrm{iU} / \mathrm{mL}$ ) to prevent breakthrough perinatal HBV transmission has also been successful without concerns. Tenofovir, lamivudine and telbivudine are nucleos(t)ide inhibitors which act as chain termination in DNA elongation and can be administered from 28 weeks of pregnancy. ${ }^{23}$

Initially lamivudine (3TC) was commonly used with benefit of reduction in transmission of $\mathrm{HBV}$ transmission; however, it was shown to be associated with development of resistance owing to its low genetic barrier. On the other hand, tenofovir, has a high barrier to resistance and has been used extensively in the setting of HIV in pregnancy. Use of tenofovir in pregnancy has resulted in 
significant reductions among mothers, without any remarkable adverse effects. ${ }^{44,45}$

Based on safety data from the ARV in Pregnancy Registry in pregnant HIV positive women who have received tenofovir and/or lamivudine or emtricitabine; tenofovir appears to be the preferred ARV, owing to its better resistance profile, and more extensive safety data in pregnant $\mathrm{HBV}$ positive mothers. ${ }^{23,43}$

As ongoing caution is being advised on the use of ART in pregnancy; the absence of adverse drug events in mothers and their infant pairs who received ART in pregnancy up to date offers promise in their use. ${ }^{44}$ Some guidelines recommend treatment for non-cirrhotic patients (including pregnant woman) with serum HBV DNA levels greater than $20,000 \mathrm{iu} / \mathrm{mL}\left(>10^{5}\right.$ copies/ $\mathrm{mL})$ and evidence of liver disaes. ${ }^{45}$

\section{Intra-partum/Neonatal}

Use of monitors should be avoided as much as possibleIn centres where it is obtainable the use of fetal scalp electrode monitoring as well as fetal blood sampling should be avoided particularly if mother is HBeAg positive. Also standard precautions should be implemented for care of all women in labour. Appropriate cleaning of the newborn should equally be practiced- upon delivery the neonate's eyes as well as the non- intact skin should be cleaned properly using water as soon as possible after birth.46

\section{Immunoprophylaxis}

The double usage of active and passive immuneprophylaxis is the ideal measure to prevent MTCT of HBV infection. $^{47}$

PEP with hepatitis B vaccine and hepatitis B immuneglobulin (HBIG) administered within 12 to 24 hours after birth followed by completion of a three dose vaccination series, has been shown to protect 85 to $95 \%$ of infants whose mothers were positive for both $\mathrm{HBsAg}$ and $\mathrm{HBeAg} .{ }^{48}$

\section{Birth dose hepatitis $b$ vaccine}

The recombinant DNA - derived hepatitis B vaccines have been available and licensed for use since 1982. The World Health Organization (WHO) as well as the Centers for Disease Control (CDC) recommends universal $\mathrm{HBV}$ vaccination for all infants, and that the first dose should be given as soon as possible after birth preferably within the first 12 hours of birth. ${ }^{47}$

In Nigeria the universal HBV vaccination was initiated by the Federal Government in 2004; despite that huge gap still exists in meeting the targets as majority of the children receive the birth dose vaccine outside the recommended time owing to maternal as well as programme - related factors. ${ }^{49,50}$

The birth dose of HBV vaccine is very important as that serves as a safety net as non-testing, errors in testing, reporting and documentation of maternal $\mathrm{HBsAg}$ status could occur. $^{51}$

In the United States, the CDC in 2005 recommended that the Advisory Committee on Immunization Practices (ACIP) and all health professionals should administer the HBV vaccine to all newborns before hospital discharge in order to protect them against the HBV ifneciton. ${ }^{52}$

However, in Nigeria it has been noted that many babies whom were delivered in health facilities do not receive the birth dose of recommended vaccinations before the hospital discharge. ${ }^{53}$ Nigeria recommends that the birth dose of HBV should be given preferably within the first 24 hours of birth but up to first 2 weeks of life. This birth dose is usually given as a monovalent vaccine. It is of note that giving the birth dose after the neonatal period reduces the efficacy of PEP which decreases with increasing time as exposure. ${ }^{54}$

\section{Nigerian HBV Vaccination Schedule}

The birth dose of HBV vaccine followed by two more doses to complete the primary series is the conventional. However, WHO recommends that four doses may be given in line with the programmatic protocol of National Schedules. ${ }^{54}$

The pentavalent vaccine which replaced the trivalent DPT was introduced in Nigeria in 2012, and contains HBV vaccine among others as a combination vaccine to be commenced at age 6 weeks through ten and 14 weeks respectively. However, Nigeria currently gives the birth dose in addition to three combined doses in form of pentavalent vaccine doses.

The complete vaccine series induces protective antibody levels in more than $95 \%$ of infants, children and young adults. Protection lasts at least 20 years and is probably life long. ${ }^{1}$ The vaccine has excellent record of safety and effectiveness and the immunogenicity of the combined hepatitis vaccines is equivalent to that of their individual antigens administered separately. ${ }^{1}$

Immunization escape mutants in the $\mathrm{S}-$ gene of $\mathrm{HBV}$ have been detected, and concerns have been expressed that these variants could replicate in the presence of vaccine induced anti-HBS or anti-HBS contained in HBIG. However no evidence exist that s-gene immunization escape mutants posing a risk to currently existing programmes using hepatitis B vaccine. ${ }^{55}$

Further studies including surveillance are needed to track any possible emergence of these variants in future.

\section{Vaccinations in preterm/Low Birth Weights}

Previously, the American Academy of Pediatrics (AAP) routinely recommended that the birth dose of HBV vaccine for preterm and low birth weight infants born to HBsAg negative mothers be delayed up till the infant 
weighed 2 kilograms or is 2 months of chronological age, ${ }^{56}$ owing to reduced immunogenicity in preterm less than two kilograms $(<2 \mathrm{~kg}) .{ }^{56}$ However recent guidelines by the AAP recommends that such children should receive the first dose of hepatitis B vaccine by 30 days of chronological age irrespective of the gestation age. Also if such preterm/LBW shows consistent weight gain necessitating hospital discharge before 30 days of age, the first dose of hepatitis B vaccine should be given at the time of hospital discharge. The remaining 3 doses of hepatitis B vaccine series should be completed on the same schedule as applicable to full term infants, ensuring that the second dose is given at least 30 days after the initial dose. ${ }^{56}$

Also of note is that currently the ACIP does not recommend routine booster doses of hepatitis B vaccine for persons who completed the primary $\mathrm{HBV}$ immunization series in childhood. ${ }^{57}$

The immunogenicity of hepatitis B vaccine is low in individuals with severe immunosuppressive states including AIDS, and timely administration of the HBV vaccine commencing at birth should be the rule rather than the exception as the HIV immunosuppression worsens overtime among infected children. ${ }^{54}$

Hepatitis B vaccination is recommended in $\mathrm{HBsAg}$ negative women in pregnancy with high likelihood of acquisition of the infection particularly in those having multiple sexual partners or intravenous drug abusers. ${ }^{58}$

\section{Passive immunization}

It provides passively acquired anti-HBS and temporary protection when administered in standard doses. Hepatitis B immuneglobulin (HBIG) is typically used as an adjuvant to the hepatitis $B$ vaccine in the PMTCT of hepatitis B infection in exposed infants, providing temporarily protection for 3 to 6 months.

Administration of hepatitis B immuneglobulin and hepatitis B vaccine within 24 hours of birth, followed by the completion of the vaccine series is $85-95 \%$ efficacious in PMTCT of HBV. ${ }^{14}$

HIBG administered alone is the primary means of protection afteran HBV exposure for non-responders to hepatitis $\mathrm{B}$ vaccination.
Follow - up

MTCT of hepatitis B virus continues to occur despite the use of adequate preventive measures including vaccinations and HBIG administration. ${ }^{13}$ The ACIP recommends post-HBV vaccination testing for all infants born to HBsAg positive women. The testing consists of HBsAg for infection and anti-HBS for response to vaccination. The optimal timing for detecting protective antibodies is one to 2 months after the final Hepatitis B vaccine dose at $\geq 9$ months of age. The testing for follow-up should commence at 9 to 18 months of age, at least 1 month after the last dose of vaccine. ${ }^{46}$

The anti-HBS levels done earlier than 9 months of age may reflect passive immunization with HBIG. ${ }^{28}$ Anti HBS levels of more than $10 \mathrm{~m} / \mathrm{u} / \mathrm{L}$ indicate adequate protection whereas babies with anti-HBs levels of less than $10 \mathrm{~m} / \mathrm{u} / \mathrm{L}$ need to be re-vaccinated with the entire 3 dose schedule.

Babies who are HBsAg positive are infected and need further evaluation and follow-up by a paediatric gastroenterologist.

Currently Nigerian Society for Paediatric Gastroenterology Hepatology and Nutrition (NISPGHAN) and Society for Gastroenterology and Hepatology in Nigeria (SOGHIN) are in the forefront of spreading the good news of HBV prevention in Nigeria and should be encouraged by the authorities by doing the needful.

\section{Conclusion \\ Universal screening of all pregnant women for HBV infection is the most effective strategy for the prevention of MTCT of HBV, as effective preventive measures could be applied starting from pregnancy to delivery while infants of HBsAg positive mothers should receive timely and adequate PEP as well as follow up for possi- ble development of chronic hepatitis B infection.}

\section{Author's contributions}

CBE: Study conceptualization, literature search, manuscript draft, critical editing of the manuscript for important intellectual content.

NBO, OFA: Critical editing of the manuscript for important intellectual content.

Conflict of Interests: None

Funding: None

\section{References}

1. World Health Organization. Hepatitis $\mathrm{B}$ fact sheet $\mathrm{N}^{\mathrm{O}} 204$. Updated July, 2015. Available from: http:// www.who.int/mediacentre/ factsheet/fs204/cn/ Accessed: $26^{\text {th }}$ December, 2015.

2. Hwang EW, Cheung R. Global epidemiology of hepatitis B virus infection. NAJ Med Sci 2011; 4:713.
3. Kiire $\mathrm{CF}$ and the African regional study group. Hepatitis B infection in Sub-Saharan Africa. Vaccine 1990; 8:S107-S112.

4. Kirre CF. The epidemiology and prophylaxis of hepatitis B in SubSaharan Africa: a view from tropical and sub-tropical Africa. Gut 1996; 37:S5-S12.
5. Okonko I, Okeretugba P, Innocent - Adiele H. Detection of hepatitis B surface antigen (HBsAg) among children in Ibadan, South Western Nigeria. The Internet Journal of Infectious Diseases 2012; 10.Available from:http://www.ispub.com/ IJID/10/1/14183.

Accessed: $18^{\text {th }}$ February, 2016 
6. Isa MA, Bellow HS, Gulani IA, Aligh B, Aisha MA, Iliya H. Prevalence of hepatitis $B$ virus infection among children attending Mohammed Shuwa Memorial Hospital Maiduguri, Bornu State Nigeria. Int J. Adv Res. Bio. Sci 2015; 2: 28-32

7. Sadoh AE, Ofili A. Hepatitis B infection among Nigerian children admitted to a children's Emergency Room. Afr Health Sci 2014; 14:377-383.

8. Ndako J, Echeonwu GO, Olabode A, Nwankiti OO, Aimakhu SO, Onoroh EM, et al. Seroprevalence of hepatitis B surface antigen (HBsAg) among children of primary school age in a community, North Central, Nigeria.

Sierra Leone J Biomed Rese 2010; 2:32-37.

9. Eke CB, Ogbodo SO, Ukoha OM, Ibekwe RC, Asinobi IN, Ikefuna AN, Ibe BC. Seroprevalence and risk factors of hepatitis B virus infection among adolescents in Enugu, Nigeria. J. Trop Paediatrics 2015;0: 1 - 7 . DOI: 10.1093/tropej/fmv035.

10. Lozano R, Naghari M, Foreman K, Lim S, Shibuya K, Aboyans V, Abraham J, et al. Global and regional mortality from 235 causes of death for over 20 age groups in 1999 and 2010: a systematic analysis for the Global Burden of Disease study 2010. Lancet 2012; 380: 2095-2128.

11 Emechebe GO, Emodi IJ, Ikefuna AN, Ilechukwu GC, Igwe WC, Ejiofor OS, et al. Hepatitis B virus infection in Nigeria - A review. Niger Med J. 2009; 50:18-22.

12 Eke AC, Eke UA, Okafor CI, Ezebialu IU, Ogbuagu C. Prevalence, correlates and patterns of hepatitis $B$ surface antigen in a low resource setting. Virology J 2011; 8:12. Available from: http:// www.virology.com/content/8/1/12. Accessed: $21^{\text {st }}$ February, 2016.

13. Nelson TV. Prevention of perinatal hepatitis B virus transmission. J. Ped. Infect Dis 2014; 3 (Suppl. I):S7-S12. Doi: 10. 1093/jpids/ pi064.

14. Centers for Disease Control and Prevention. Viral Hepatitis Hepatitis B perinatal transmission. Available from: www.cdc.gov/ hepatitis/hbv/perinatalxmtn.htm Accessed: $26^{\text {th }}$ December, 2015.
15. Luka SA, Ibrahim MB, Iliya SN. Seroprevalence of hepatitis B surface antigen among pregnant women attending Ahmadu Bello University Teaching Hospital Zaria Nigeria. Niger J Parasitol 2008;29:38-41.

16. Pondei K, Ibrahim I. The seroprevalence of hepatitis B surface antigen and anti-hepatitis $\mathrm{C}$ antibody among women attending antenatal clinic at a tertiary health facility in the Niger Delta of Nigeria. Global Adva Res J Med Medical Sci 2013; 2: 006-012.

17. Aganga - Williams OM, Akanmu AS, Akinsete I, Njoku OS. Prevalence of hepatitis B surface antigen among women of child bearing age in Lagos, Nigeria. Afr J Repro Health 1999; 3:45-50.

18. Giles ML, Grace R, Tai A, Michalak K, Walker SP. Prevention of mother-to-child transmission of hepatitis B virus (HBV) during pregnancy and the peurperium: Current standards of care. Aust NZJ Obst Gynaecol 2013; 53 (3):231-235.

19. Forbi JC, Iparepolu OH, Zungwe T, Agwale SM. Prevalence of hepatitis $\mathrm{B}$ e- antigen in chronic HBV carriers in North Central Nigeria. J Health Popul Nutr 2012; 30:377-382.

20. Yakassai IA, Ayyuba R, Abubakar S, Ibrahim SA. Seroprevalence of hepatitis B virus infection and its risk factors among pregnant women attending antenatal clinics at Aminu Kano Teaching Hospital Kano, Nigeria. J Basic Clin Reprod Sci 2012; 49-55.

21. Nelson NP, Jamieson DJ, Murphy TV. Prevention of perinatal hepatitis B virus transmission. $J$ Ped Infect Dis 2014; 3(Suppl.I): S7-S12 DOI: 10.1093/jpids/pi064.

22. Anderson MI, Rajbhaudari R, Kew MC, Vento S, Preiser W, Hoepelman AIM, et al. Mother-to-childtransmission of hepatitis B virus in sub-Saharan Africa - time to act. Lancet Global Health 2015; 3(7) e358-e359 DOI: http:// dx.doi.org/10.1016/-S2214-109X (15)00056-x.

23. Anderson M. Mother-to-child transmission of hepatitis B in Africa: is elimination feasible? March 2015 Available from:http:// www.sacemaquarterly.com/wpcontent/uploads/2015/03/ Andersson-mother-to-child-article1.pdf. Accessed: $1^{\text {st }}$ February, 2016.
24. Yazigi N, Balistreri WF. Viral hepatitis In: Kliegman RM, Behrman RE, Jenson HB, Stanton BF (editors) Nelson textbook of pediatrics, $18^{\text {th }}$ ed. Sanders Elsevier, United State of America 2007; 1680-1690.

25. Crawford JM. The liver and the biliary tract. In: Cotran RS, Kamar V, Collins T (editors) Robbins Pathologic basis of disease. Philadelphia (USA), W.B. Saunders Company. pp. 845-901.

26. Cheung KW, Seto MT, Wong SF Towards complete eradication of hepatitis B infection from perinatal transmission: review of the mechanisms of in -utero infection and the use of anti-retroviral treatment during pregnancy. Eur J. Obstet Gynecol Reprod Biol 2013;169:17-23.

27. Hepatitis B - Mother to child (perinatal) transmission prevention. Available from: http:// www.depts.washington.edu/ hepstudy/hepB/prevention/ perinatal/discussion.html. Accessed: $28^{\text {th }}$ December, 2015.

28. Xu DZ, Yan YP, Choi BC, Xu JQ, Men K, Zhang JX, et al.Risk factors and mechanism of transplacental transmission of hepatitis B virus: a case control study. $J$. Med. Virol 2002; 67:20-26.

29. Van Damme P, Ward J, Shoural D, Wiersma S, Zanetti A. Heptatitis B vaccines. In: Plotkin $S$, Orenstein W, Offit P, eds. Vaccines.China:Saunders;2012; pp.183-204.

30. Bai H, Zhang L, Ma L, Dou X-G, Feng G-H, Zhao G-Z. Relationship of hepatitis B virus infection of placental barrier and hepatitis $B$ virus intra - uterine transmission mechanism. World J Gastroenterol 2007; 13:3652-3630.

31. Towers CV, Asrat T, Rummey P. The presence of hepatitis B surface antigen and deoxyribonucleic acid in amniotic fluid and cord blood. Am J Obst Gynecol 2001; 184: 1514-1518.

32. Zhang SL, Yae YF, Bai GQ, Shi L, Jiang H. Mechanism of intrauterine infection of hepatitis B virus. World J Gastroenterol 2004; 10:437-438.

33. Chang MH. Hepatitis B virus infection. Semin fetal Neonatal Med 2007; 12:160-167. 
34. World Health Organization. Guidelines for the prevention, care and treatment of persons with chronic hepatitis B infection. March 2015. Available from: http://www.apps.who.int/iris/ bitstream/ 10665/154590/1/9789241549059_ eng.pdf Accessed: $20^{\text {th }}$ February, 2016.

35. Mast EE, Margolis HS, Fiore AE, Brink EW, Goldstein ST, Wang SA, et al. A comprehensive immunization strategy of eliminate transmission of hepatitis B virus infection in the United States: Recommendations of the advisory committee on Immunization of infants, children and adolescents. CDC: MMWR Dec. 23, 2005/54 (RR16); 1-23. Available from: http://www.cdc.gov/mmwr/ preview/mmwrhtml/rr5416aI.Hm? S-cid=rr5416a1e Accessed: $25^{\text {th }}$ December, 2015.

36. Testing for hepatitis B virus infection during pregnancy flowchart for prenatal providers. Available from: www.CDC.gov/ hepatitis/perinatalHepB Accessed: 25 ${ }^{\text {th }}$ December, 2015.

37. Screening for hepatitis B virus infection in pregnancy: United States preventive Services Task Force Re-affirmation Recommendation Statement. Ann. Intern. Med.2009;150:869-873.

38. Zhaug WI, Zhao J, Li W. Influencing factors of mother infant vertical transmission of hepatitis B virus. Zhuguo Dang Dai Er Ke Za Zhi 2011; 8(3):644-646.

39. Greenup AJ, Tan PK, Nguyan V, Glass A, Davison S, Chatterjee U, et al. Efficacy and safety of tenofovir disproxil fumerate in pregnancy to prevent perinatal transmission of hepatitis Bvirus. $J$. Hepatol 2014; 61:502-507.

40. Celen MK, Mert D, Aj M, Dal T, Kaya S, Yildirim N, et al. Efficacy and safety of tenofovir disproxil fumerate in pregnancy for the prevention of vertical transmission of HBV infection. World J. Gastroenterol 2013; 19:9377-9382.
41. Han $\mathrm{CR}, \mathrm{Xu} \mathrm{Cl}$, Zhao W, Yang YF. Management of chronic hepatitis B in pregnancy. World J. Gastroenterol 2012; 18:4517-4521.

42. Beasley RP, Hwang LY, Stevens $\mathrm{CE}$, Lin CC, Hsieh FJ Wang KY, et al. Efficacy of hepatitis B immune globulin for prevention of perinatal transmission of the hepatitis B virus carrier state: final report of a randomized double blind, placebocontrolled trial. Hepatology 1983; 3: 135-141.

43. Do EC, Ghang MG. Hepatitis B virology for clinicians. Med. Clin. North Am. 2010;14:397-408.

44. Wang L, Kourtis AP, Ellington S, Legardy - Williams J, Bulterys M. Safety of tenofovir during pregnancy for the mother and fetus: a systemic review. Clin. Infect. A Dis 2013; 57:1773-1781.

45. Bzowej NH. Optimal management of the hepatitis B patient who desires pregnancy or is pregnant. Curr. Hepat Rep 2012; 11:82-89.

46. Royal Hospital for women: Clinical policies, procedures and guidelines, 2012 Available from: http// www.seslhd.health.new.gov.au/ rhw/manuals/documents/ Neonatology/Accessed: $3^{\text {rd }}$ April, 2016.

47. Geeta MG, Riyaz A. Prevention of mother to child transmission of hepatitis B infection. Indian Pediatrics 2013; 50:189-192.

48. Andre FE, Zuckerman AJ. Protective efficacy of hepatitis B vaccines in neonates. J Med Virol 1994; 44:144-151.

49. Sadoh AE, Sadoh WE. Does Nigeria need the birth dose of hepatitis B vaccine? Niger J Paed 2014; 41 . 104-109.

50. Sadoh AE, Sadoh WE. Serological markers of hepatitis B infection in infants presenting for their first immunization. Niger J Paed. 2013; 40:248-253.

51. Anderson TA, Wexler DL. States report hundreds of medical errors in perinatal hepatitis B prevention. St. Paul, MN: Immunization Action Coalition; 2005. Available from: Http://www.immunize.org/ catg.d/p2062.htm. Accessed: $15^{\text {th }}$ February, 2016.
52. Hashemi - Shahri SM, SharifiMood B, Khalili M. Review of the prevention of the hepatitis $B$ virus infection transmission from mother to child during pregnancy. Int J. Infect 2015; 2: e26626.

53. Sadoh AE, Eregie CO. Timeliness and completion rate of immunization among Nigerian children attending a clinic - based immunization service. $J$ Health Popul Nutr 2009; 27:391-395.

54. World Health Organization. Hepatitis B vaccines. WHO position paper. Weekly Epidemiol Rec. 2009; 84: 405-420.

55. Mele A, Tancredi F, Romano L, of hepatitis $B$ vaccination in babies born to hepatitis B surface antigepositive mothers in Italy. $J$. Infect Diseases 2001; 184:905908.

56. Saari TN; American Academic of Pediatrics Committee on Infections Diseases. Immunization of preterm and low birth weight infants. American Academy of Pediatrics Committee on Infectious Diseases. Pediatrics 2003; 112: 193-198.

57. Hepatitis B virus: A comprehensive strategy for eliminating transmission in the United States through universal childhood vaccination: recommendations of the immunization practices Advisory Committee (ACIP).MMWR 1999; 40(RR-13): 1-25.

59. Mangione R, Stroffolini T, Tosti ME, Fragapani P, Mele A. Delayed third dose hepatitis $B$ vaccine dose and immuneresponse. Lancet 1995; 345: 1111-1112. 